\title{
Újdonságok a gyermekkori immunthrombocytopenia kezelésében - 2017
}

\author{
Kovács Gábor dr. ${ }^{1}$ - Kiss Csongor dr. ${ }^{2}$ \\ ${ }^{1}$ Semmelweis Egyetem, Általános Orvostudományi Kar, II. Gyermekgyógyászati Klinika, Budapest \\ ${ }^{2}$ Debreceni Egyetem, Általános Orvostudományi Kar, Gyermekgyógyászati Klinika, Debrecen
}

\begin{abstract}
A gyermekkori immunthrombocytopenia (ITP) nagyon változatos kórkép. A különböző nemzetközi ajánlások nem szabnak meg szigorú előírásokat, csupán terápiás lehetôségekról beszélnek. A hazai gyakorlat alapján 2011-ben egy konkrét terápiás algoritmus került bemutatásra. Az elmúlt években új innovatív szerek állnak rendelkezésre már Magyarországon is, ezért időszerű a terápiás ajánlások átgondolása és újrafogalmazása. A jelen munkában napjaink korszerú ellátási elveit mutatjuk be. Csecsemő- és gyermekkorban továbbra is elsősorban a nagy adagú intravénás immunglobulin-kezelést javasoljuk, idősebb életkorban és alternatívaként a szteroidkezelés is indikált (lökéskezelés vagy elnyújtott kis adagú kezelés formájában). Rezisztens esetekben az új, innovatív trombopoetinreceptor-izgató szerek közül ma már gyermekeknek is törzskönyvezett készítmény az eltrombopág, amely nagyon hatékonyan javítja a kórlefolyást. A lépkivétel gyermekkorban csak kivételes esetben jön szóba. Az ITP kiszámíthatatlan kórkép, és bár gyermekkorban mintegy 70-80\%-ban gyógyul, szakorvosi ellátást és hosszú távú követést igényel.

Orv Hetil. 2017; 158(48): 1891-1896.
\end{abstract}

Kulcsszavak: gyermekkori ITP, vérzés, terápiás ajánlás, immunglobulin, trombopoetinreceptor

\section{Novelties in the treatment of pediatric immune thrombocytopenia -2017}

Immune thrombocitopenia in children is a very variable disease. International recommendations give therapeutic possibilities without strong protocols. In 2011 , a therapeutic algorithm was published based on Hungarian practice. Recently, new innovative drugs have been available even in Hungary, so there is a need for modification of the therapeutic protocols. In this summary we give an overview about the current up-to-date management. In infancy and in childhood, high-dose immunglobulin treatment is recommended henceforward. In older children an alternative can be steroid therapy (pulses or long-term low-dose treatment). In resistant cases, a new thrombopoetin receptor stimulant, eltrombopag can be administered. This drug is registered in Hungary, and can very effectively influence the prognosis. Splenectomy is very rare nowadays in children. Immune thrombocytopenia is an unpredictable disease. Cure rate is about $70-80 \%$ of the cases, but management of the patients needs special care and specialist.

Keywords: pediatric ITP, bleeding, therapeutic recommendation, immunglobulin, thrombopoetin receptor stimulant

Kovács G, Kiss Cs. [Novelties in the treatment of pediatric immune thrombocitopenia - 2017]. Orv Hetil. 2017; 158(48): 1891-1896.

(Beérkezett: 2017. szeptember 15.; elfogadva: 2017. október 12.)

Az Orvosi Hetilap alapításának 160. évében a Szerkesztőség felkérésére készült tanulmány.

\section{Rövidítések}

$\mathrm{ALL}=$ (acute lymphoid leukemia) heveny nyiroksejtes leukaemia; $\mathrm{DAT}=($ direct antiglobulin test $)$ direkt antiglobulin(Coomb's) teszt; EBV = Epstein-Barr-vírus; $\mathrm{HCV}=$ hepatitis
C-vírus; HIV = humán immundeficientia-vírus; HPA = humán thrombocyta-antigén; ITP = (immune thrombocytopenic purpura) immunthrombocytopenia; IVIG $=$ (intravenous immunoglobulin) intravénás immunglobulin-kezelés; OGYÉI = Or- 
szágos Gyógyszerészeti és Élelmezés-egészségügyi Intézet; PAIG $=$ (platelet-associated immunoglobulin) vérlemezkéhez kapcsolt immunglobulin; THR $=$ (thrombocyta) vérlemezke; TORCH = toxoplasma, rubeola, cytomegalovirus, herpeszvírus; $\mathrm{TPO}=$ trombopoetin; $\mathrm{VZV}=$ varicella zoster vírus

$\mathrm{Az}$ (auto)immunthrombocytopenia (ITP) izolált, immunmediált, thrombocyta (THR)-destrukció következtében kialakuló, vérzékenységgel járó, szerzett betegség. Gyermekkori ITP-ben a fiúk és lányok közel egyforma gyakorisággal érintettek, a betegség kettő-négy éves kor között fordul elő a leggyakrabban. Primer és szekunder kórképet különböztetünk meg [1]. Előbbi esetben az immunrendszer kisiklásának oka ismeretlen, utóbbi esetben a betegség egyéb immun-patomechanizmusú folyamathoz vagy fertôzéshez, védôoltáshoz társul (1. táblázat). A gyermekkori ITP általában jóindulatú, az esetek egy része spontán gyógyul, míg a többsége kezelés mellett rendeződik. A gyógyulást relapsusok, exacerbatiók szakíthatják meg. Amennyiben a tünetek vagy a thrombocytopenia három hónapon túl fennállnak, perzisztáló ITP-ről beszélünk. A betegséget egyéves fennállás után krónikus ITP-nek nevezzük. Ebbe a kategóriába kerül a betegek körülbelül 20-25\%-a.

A letalitás igen ritka, az esetek $<0,1 \%$-ában bekövetkező központi idegrendszeri vérzés okozhatja. A betegség incidenciájára vonatkozóan az adatok széles határok között változnak: 20-125/1 000000 [2]. Az ITP-s gyermekek többsége a vérzéses tünetek jelentkezése előtt kettő-hat héttel fertőző betegségen esett át. Valószínúleg emiatt a gyermekkori ITP őszi-téli halmozódást mutat.

A kórfolyamat lényege, hogy autoantitestek reagálnak a vérlemezkék glikoproteinreceptoraival. Az opszonizált thrombocytákat macrophagok kebelezik be. A phagocytosist az immunglobulin-molekulák Fc-porciója vagy az esetek egy részét jellemző komplementaktivációt követő sejtfelszíni C3b-fixálás triggereli. A döntően extravascularisan zajló destrukció a leggyakrabban és a legkifejezettebb mértékben a lépen történik.

1. táblázat |A szekunder ITP okai

Antifoszfolipid-szindróma

Autoimmun betegségek (Evans-szindróma)

Gyógyszermellékhatás (például heparinindukált thrombocytopenia)

Immundeficientia-szindrómák (elsősorban CVID)

Infekciók (elsősorban CMV-, HCV-, HIV-, VZV-, H. pylori-fertőzések)

Védőoltások (elsősorban MMR)

Lymphoproliferativ betegségek, myelodysplasiás szindróma

Szervtranszplantáció (elsősorban allogén őssejt-transzplantáció)

$\mathrm{CMV}=$ cytomegalovirus; $\mathrm{CVID}=$ egyszerű kevert immunhiány; $\mathrm{HCV}=$ hepatitis $\mathrm{C}$-vírus; HIV = humán immundeficientia-vírus; ITP = immunthrombocytopenia; $\mathrm{MMR}=$ morbilli-mumpsz-rubeola; $\mathrm{VZV}=$ varicella zoster vírus
A perifériás THR-destrukcióval párhuzamosan, de annak ütemétôl és mértékétôl elmaradva, az esetek többségében fokozódik a megakaryopoesis. Kísérletes adatok szerint, elsősorban krónikus ITP-ben, a betegek mintegy $40 \%$-ában, a fokozott perifériás vérlemezke-pusztulás mellett a csontvelóképzés is csökken. A THR-ellenes autoantitestek termelődését kiváltó tényezőket kevéssé ismerjük. Az immunreguláció zavarához hozzájárulhat a „molekuláris mimikri” és az „epitopkiterjedés” jelensége, valamint - elsősorban krónikus ITP-ben - a centrális és perifériás immuntolerancia-mechanizmusok károsodása. Neonatalis ITP-ben az autoantitestek az anya szervezetében termelődnek (akár splenectomián átesett, tünetmentes, normális THR-számmal élők esetében is), és a placentán átjutva a magzatban okoznak THR-pusztulást. Neonatalis alloimmun thrombocytopeniában a magzati THR-ek szenzitizálják az anya szervezetét, amely alloantitesteket termel a számára idegen, magzati THR-antigénnel (többnyire a HPA-l antigénnel) szemben. A magzati, illetőleg újszülöttkori THR-destrukciót ebben az esetben a placentán átjutó anyai THR-ellenes alloantitestek idézik elő [3].

\section{Diagnózis}

Az ITP kizárásos kórisme. Alapvető a nyilvánvaló thrombocytopenia (THR<100 G/l) megállapítása és egyéb, thrombocytopeniához vezető kórállapotok kizárása. A kórismézés alkalmával megállapított thrombocytaszám többnyire 10-20 G/1 között van a gyermek betegek mintegy háromnegyedében. A kórismézés a jellegzetes kórtörténeten, fizikális és laboratóriumi eltéréseken alapul [4].

Az anamnézisben keresni kell a megelőző vírusinfekcióra utaló (aktuálisan már rendszerint infekciómentes) adatokat, valamint a szekunder ITP lehetséges kórokát képező alapbetegségre utaló kórtörténeti adatokat.

A vérzéses tünetek az egyébként általában egészséges gyermekben hirtelen, váratlanul lépnek fel. Jellegzetesen thrombocyta típusú vérzéses tüneteket észlelünk: a bőrön purpurák, petechiák, felszínes suffusiók láthatók (innen ered a betegség korábban használt neve: idiopathiás/immunthrombocytopeniás purpura). Petechiás vérzések a nyálkahártyákon is kialakulhatnak. Gyakori az epistaxis és a serdült leányokban a menorrhagia. Jellegzetes a sebzések elhúzódó vérzése és a sérülékenység. Ritka a lumenes szervek vérzése. A betegek $<0,1 \%$-ában retinavérzés, központi idegrendszeri vérzés is felléphet. Ritkán kismértékű lépmegnagyobbodást tapintunk.

\section{Laboratóriumi vizsgálatok}

\section{Kvantitatín és kvalitatín vérkép}

Thrombocytopenia (általában az egyetlen eltérés), a thrombocyták a normálisnál nagyobb méretúek (vagy normális nagyságúak). A betegség kórismézéséhez $<100$ 
G/1 THR-szám és típusos vérzéses tünetek vagy két hónap különbséggel ismételten észlelhető thrombocytopenia (<100 G/l) szükséges. A vörösvérsejtek és a fehérvérsejtek morfológiája normális, enyhe eosinophilia előfordulhat. A kenetben néha aktivált, nagy lymphocytákat látunk. Anaemia fennállhat a vérzések, Evans-szindrómában a társuló haemolysis miatt. Tartós vérezgetéssel járó, elhúzódó ITP-ben az anaemia hypochrom, microcytaer; vashiány igazolható. Az Evans-szindrómához autoimmun neutropenia társulhat.

\section{Csontvelóvizsgálat}

Típusos esetben a megakaryocyták száma emelkedett. Ritkán megakaryocytopenia is előfordulhat, ha a hozzájuk kötődő autoantitestek képződésüket gátolják vagy citotoxikusak. Csontvelővizsgálat elvégzésére újonnan diagnosztizált ITP-ben akkor van szükség, ha a beteg kortikoszteroidkezelését tervezzük, ugyanis alkalmazása elfedheti az akut lymphoblastos leukaemia (ALL) vagy más csontvelőbetegség képét, és tartós monoterápiaként kedvezőtlenül befolyásolja a kórlefolyást. Ugyancsak elvégezzük a csontvelővizsgálatot szekunder és perzisztáló ITP-ben.

\section{Szerológiai vizsgálatok}

Az emelkedett THR-asszociált IgG- (PAIG, thrombocytaasszociált $\mathrm{Ig}_{-}$) szint vizsgálata a rutindiagnosztikában nem szükséges, nincs terápiás konzekvenciája. Egyéb autoimmun kórkép gyanúja esetén egyéb autoimmunmarkerek vizsgálata szóba jön (például antifoszfolipidszindróma). Infektív ágensek keresése lehetséges (HIV, HCV, parvovírus B19, VZV, EBV, TORCH, H. pylori), de általában terápiás konzekvenciája nincs.

\section{Vércsoport-meghatározás}

Esetleges transzfúzió szükségessége miatt.

\section{Immunglobulin (Ig)-meghatározás, direkt antiglobulin- (Coomb's) teszt (DAT)}

$\mathrm{Az}$ alacsony Ig-szintek immundeficientiára utalnak, a DAT-pozitivitás haemolysist jelez.

\section{Egyéb vizsgálatok}

Képalkotó vizsgálatok, kromoszómavizsgálat, molekuláris genetikai vizsgálat, THR-aggregáció és „release” vizsgálatok végzése differenciáldiagnosztikai okokból válhat szükségessé.

Az ITP elkülönítő kórisméjében szerepet játszó legfontosabb kórképek a 2. táblázatban láthatók.

\section{2. táblázat $\mid$ Az ITP differenciáldiagnózisa}

Hiporegenerativ thrombocytopeniák: constitutionalis és akvirált aplasztikus anaemiák (congenitalis megakaryocytás thrombocytopenia, $\mathrm{X}$-hez kötött thrombocytopenia, thrombocytopenia a radiusok hiányával (TAR-s.), Fanconi-anaemia, Alport-szindróma, Wiskott-Aldrich-szindróma, sugárártalom vagy myelosuppressiv gyógyszeres kezelés következtében kialakuló thrombocytopenia, csontvelö-infiltrációt okozó betegségek (akut leukaemia, myelodysplasiás szindrómák, csontvelőt infiltráló szolid tumorok, raktározási betegségek), súlyos senyvesztő betegségek, súlyos malnutritio, újszülött/csecsemőkori folsav-, illetve $\mathrm{B}_{12}$-vitamin-hiány

Nem immun-THR-destrukció: microangiopathiás kórképek (HUS, TTP, DIC), macroangiopathiás destruktív thrombocytopenia (Kasabach-Merritt-szindróma, vitium), hypersplenia, sequestratio. Elörehaladott szepszisben a képzés zavara és a fokozott pusztulás egyaránt fennállhat

Egyéb immunpatomechanizmusú thrombocytopeniák: alloimmun thrombocytopeniák (neonatalis alloimmun thrombocytopenia, poszttranszfúziós, poszttranszplantációs purpura), autoimmun kórképekhez társuló, drog-, terhesség-, HIV-fertőzés-indukált immunthrombocytopeniák

Thrombocytopeniával járó THR-funkció-zavarok: Bernard-Soulierszindróma, szürke THR-szindróma

Miozin-nehézlánc-9 (MYH-9)-mutációk és társuló betegségek (Epstein-, Fechtner-, Sebastian-, May-Hegglin-anomália)

Újszülöttekben komplex etiológiával thrombocytopeniát okozhat a neonatalis ITP, a neonatalis alloimmun thrombocytopenia, intrauterin infekciók (TORCH-szindróma, connatalis lues), súlyos perinatalis fertőzések, szepszis, DIC, NEC, vércsere-transzfúzió, fototerápia

Pseudothrombocytopenia (EDTA-agglutinatio)

DIC = disszeminált intravascularis koaguláció; EDTA = etilén-diamin tetraacetát; HUS = haemolyticus uraemiás szindróma; ITP = immunthrombocytopenia; NEC = nekrotizáló enterocolitis; TAR = thrombocytopenia a radiusok hiányával; $\mathrm{THR}=$ vérlemezke; $\mathrm{TORCH}=$ toxoplasma, rubeola, cytomegalovirus, herpeszvírus; TTP $=$ thromboticus thrombocytopeniás purpura

\section{Kezelés}

A kezelés célja a súlyos, potenciálisan fatális vérzések megelőzése és a lehetőség szerinti korlátozásmentes életmód biztosítása jelentős terápiás mellékhatások és szövődmények elkerülésével [5-9].

- Feltétlenül szükségesnek tartjuk az ITP kezelését $(<50 \mathrm{G} / \mathrm{l})$ súlyos, életveszélyes vérzés (intracranialis vérzés, retinavérzés, kivérzéssel járó belszervi vérzés) fellépése esetén.

- Kiterjedt bélvérzés vagy csillapíthatatlan nyálkahártya-, illetve orrvérzés esetén is szükséges a kezelés, ha a thrombocytaszám $<50 \mathrm{G} / 1$.

- Javasoljuk a kezelést súlyos thrombocytopeniában $(<10 \mathrm{G} / \mathrm{l})$.

- Minden egyéb esetben (például ha csak bőrvérzések vannak) érdemes várakozni, mert az esetek körülbelül 20\%-ában a gyermekkori ITP spontán javul, illetve gyógyul (mindenféle kezelés nélkül).

- Kis sebészeti beavatkozásokhoz és foghúzáshoz 50 G/l-es thrombocytaszámot javasolunk, lumbálpunk- 
cióhoz $30 \mathrm{G} / \mathrm{l}$-t, míg nagyobb sebészeti mütétekhez $80 \mathrm{G} / \mathrm{l}$-t. A csontvelővizsgálat bármilyen thrombocytaszám mellett elvégezhető! (Pótlás nem szükséges.)

- Általánosságban elmondható, hogy ITP-ben a thrombocytakoncentrátum adásától lehetőség szerint tartózkodni kell, mert az ellenanyagképzést fokozza, és az alapbetegséget ronthatja. Csak életveszélyes, illetve súlyos fenyegető vérzés esetén indokolt a transzfúzió (és esetleg az előbb felsorolt mütéti szituációkban).

\section{Újszülöttek kezelése}

Neonatalis alloimmun vagy autoimmun thrombocytopeniában $(<30 \mathrm{G} / \mathrm{l})$ intravénás immunglobulin (IVIG)-kezelés javasolt $1 \mathrm{~g} / \mathrm{kg}$ dózisban. A kezelés megismételhető 48-72 órán belül, ha nincs megfelelő terápiás válasz (a thrombocytaszám nem emelkedik $50 \mathrm{G} / 1$ fölé, vagy visszaesik $30 \mathrm{G} / 1$ alá). Életveszélyes vérzés, intracranialis vérzés esetén thrombocytaszupplementáció, anaemizálódás esetén vörösvérsejt-koncentrátum adása lehet szükséges.

\section{Csecsemők kezelése}

Három hónapos és egyéves kor között is mindenképpen az IVIG-kezelést kell alkalmazni $(0,8-1 \mathrm{~g} / \mathrm{kg})$. Amenynyiben a THR-szám 48-72 órán belül nem emelkedik 20 G/l fölé, akkor a kezelés megismétlendő. Kedvező esetben is az IVIG hatása általában csak kettő-négy hétig tart. Ezen idő alatt viszont a folyamat meggyógyulhat, és további kezelésre sokszor nincs szükség. Ha viszont a thrombocytaszám ismét leesik, akkor a kezelés további egy-két alkalommal megismételhető.

A szteroidkezelést (a kifejezett mellékhatások miatt) nem javasoljuk egyéves kor alatt. Ha még sincs más lehetőség, akkor csak minimális adagban adjuk (0,3-1,0 $\mathrm{mg} / \mathrm{kg}$ )! Nagy dózisú szteroidlökést (10-20 mg/kg) lehetőleg ne alkalmazzunk!

\section{Gyermekkori akut ITP kezelése}

\section{Intravénás immunglobulin}

Intravénás immunglobulin (IVIG) $0,8-1,0 \mathrm{~g} / \mathrm{kg}$ adagban adandó, amely 48-72 óra múltán ismételhető (ha nincs megfelelő terápiás válasz). Serdülőkorig (10-12 év) mindenképpen az IVIG-kezelést javasoljuk első választásként! Az IVIG-kezelés lényegesen kevesebb mellékhatással jár, mint a szteroidkezelés, közel azonos terápiás hatékonyság mellett. A primer IVIG-kezelés mellett szól az a tény is, hogy a fiatalabb gyermekek esetében több az akut lefolyást mutató kórkép. Életveszélyes vérzéssel járó ITP-ben az IVIG-kezelés adható 6-metilprednizolon alkalmazását követően is.

\section{Szteroidkezelés}

Lehetőség szerint minél kisebb adagban adjunk szteroidot, így elsősorban „hagyományos” adag (1-2 mg/kg) prednizolon/metilprednizolon per os alkalmazását javasoljuk négy-nyolc héten át. Alternatív lehetőség a prednizolon orális alkalmazása $4-5 \mathrm{mg} / \mathrm{kg}$ dózisban négy napon át, majd további kettő-négy héten át, csökkenő dózisban. Súlyos vagy fenyegető nagyobb vérzés, illetve hatástalanság esetén szóba jön a szteroid-lökésterápia. Ennek lényege a parenteralis, nagy dózisú glükokortikoid (6-metilprednizolon $10-20 \mathrm{mg} / \mathrm{kg} / \mathrm{nap}$, három napig), amelyet csökkenő dózisban három-hat hétig orális glükokortikoidkezelés követ. A mellékhatások megelőzése/mérséklése érdekében káliumpótlás, $\mathrm{H}_{2}$-receptorantagonista vagy protonpumpagátló gyógyszer alkalmazása és szénhidrátszegény étrend javasolt. A szteroidkezelést inkább a nagyobb gyermekekben (>10-12 év) javasoljuk, monoterápiában vagy IVIG-gel kombinálva. A fiatalabb korosztály számára pedig az IVIG-re rezisztens esetekben jön szóba.

\section{Thrombocytaszupportáció}

Akut életveszélyben, fenyegető intracranialis vérzés esetén thrombocytaszupportáció szóba jön 6-metilprednizolonnal és IVIG-gel. Transzfúzió adása csak súlyos anaemia társulása esetén indokolt.

\section{Szupportín kezelés}

Súlyos nyálkahártyavérzés (kivéve húgyúti vérzés!) csökkentésére antifibrinolitikum (tranexámsav, iv. 2-3 × 10 $\mathrm{mg} / \mathrm{kg} / \mathrm{nap}$, per os: $2-3 \times 20-25 \mathrm{mg} / \mathrm{kg} / \mathrm{nap}$ vagy epszilon-aminokapronsav, négy-hat óránként 0,05-0,07 $\mathrm{g} / \mathrm{kg}$, maximum $0,43 \mathrm{~g} / \mathrm{kg} /$ nap) alkalmazása javasolható. A menstruációs vérzés hormonális kezeléssel történő felfüggesztése javasolt.

\section{Második vonalbeli kezelés}

Az első vonalbeli kezelésre nem reagáló, súlyos vérzéssel társuló, perzisztáló ITP-ben válhat szükségessé második vonalbeli kezelés. Amennyiben a primer kezelés IVIG volt, akkor szteroidkezelés javasolt, ha pedig szteroid(lökés)kezelés volt az első választás, akkor IVIG javasolható. További, törzskönyvezett, jól használható, második vonalbeli gyógyszer az azatioprin (1-3 mg/ ttkg/nap). Azatioprinkezelés mellett az esetek nagy részében a szteroid elhagyható vagy minimálisra csökkenthető. A gyógyszer jól tolerálható, hosszan tartó kezelés mellett is csak ritkán jelentkeznek enyhe mellékhatások (májfunkciózavar, leukopenia). A többi számításba jövő készítmény ebben az életkorban és indikációban nincsen törzskönyvezve - vinkrisztin $0,02 \mathrm{mg} / \mathrm{kg}$ iv., hetente egyszer, négy-hat alkalommal; ciklosporin-A 2,5$3,0 \mathrm{mg} / \mathrm{kg} / \mathrm{nap}$ per os; ciklofoszfamid ( $2 \mathrm{mg} / \mathrm{kg} / \mathrm{nap}$ 
per os), merkaptopurin (25-50 mg/m²) -, és egyre kevésbé is használjuk őket [10]. Az újabb irodalmi adatok és egyes ajánlások már az új innovatív TPO-stimuláló készítményeket is a másodvonalban említik (l. később).

\section{Gyermekkori krónikus ITP kezelése}

Gyermekkorban a 12 hónapnál tovább perzisztáló ITP-t tekinthetjük krónikus ITP-nek. Fel kell hívni a figyelmet, hogy gyermekkorban (fóleg fiatalabb életkorban) még a krónikus ITP is meggyógyulhat.

Kedvező IVIG-terápiás effektus esetén a készítmény ismételt adása válhat szükségessé három-négy hetenként. A gyakori kezelést akadályozzák az ismételt IVIG-kezelések körülbelül 20\%-ában előforduló mellékhatások (láz, szédülés, hányás, anaphylaxia, idegrendszeri tünetek, veseelégtelenség stb.) és a készítmények magas ára.

A fó kezelési módot a szteroidok jelentik. A glükokortikoidokat a mellékhatások csökkentése érdekében a lehető legkisebb dózisban, lehetőleg alternáló gyógyszerbevitel formájában alkalmazzuk (másnaponta $0,3-$ $0,5 \mathrm{mg} / \mathrm{kg}$ metilprednizolon). Újabb ajánlások szerint kedvező terápiás effektus és mellékhatásprofil várható nagy dózisú 6-metilprednizolon háromnapos vagy nagy dózisú dexametazon $\left(28-40 \mathrm{mg} / \mathrm{m}^{2}-\right.$ nem törzskönyvezett indikáció) egyszeri adásától. A hatás gyakran átmeneti, ismétlés válhat szükségessé.

Glükokortikoidigényt csökkentő hatásuk miatt szóba jön a perzisztáló gyermekkori ITP második vonalbeli kezelésére ajánlott gyógyszerek kombinációban történő alkalmazása (elsősorban az azatioprin).

\section{Trombopoetin (TPO)-receptor-izgatók}

A splenectomiára nem bocsátható vagy arra kedvezőtlenül reagáló krónikus ITP-s gyermek betegek alternatív terápiára szorulnak. A krónikus ITP kezelésében használt első és másodvonalbeli gyógyszerek eredménytelensége esetén ígéretes terápiás lehetőségnek tünik a trombopoetinreceptor-serkentők alkalmazása. Az eltrombopág egy per os adható készítmény. Gyermekkori ITP-ben (egyéves kor felett) törzskönyvezett készítmény 2016 óta. A javasolt dózis $25 \mathrm{mg}$ hatéves kor alatt és $50 \mathrm{mg}$ hatéves kor felett. Idősebb gyermekeknek is érdemes kisebb adaggal kezdeni, mert gyakran az is hatásos. A rendelkezésre álló irodalmi adatok szerint a hatékonyság 60-80\% [11-14]. Mellékhatásai enyhék, ritkák (májfunkció-emelkedés, neutropenia, fertőzések), a szer általában jól tolerálható. A legújabb adatok alapján hosszú távú alkalmazása is biztonságos. Egyes esetekben thrombosist, cataractát említenek.

A subcutan adható romiplosztim olyan „peptibody”, amely nem provokál immunválaszt a készítmény ellen, és felnőtt betegeknél már hatékonyan alkalmazták. Gyermekeknél hazánkban egyedi engedély alapján (OGYÉI), a romiplosztim „off-label” alkalmazása szóba jön (jelenleg folynak a törzskönyvezési vizsgálatok). A kezdeti dózis 1-2 $\mu \mathrm{g} / \mathrm{kg} /$ hét, kéthetente $2 \mu \mathrm{g} / \mathrm{kg} /$ hét dózissal emelve, legfeljebb $10 \mu \mathrm{g} / \mathrm{kg} /$ hét maximális dózis eléréséig. A kezdeti eredmények biztatóak, rezisztens esetekben is jó hatást érhetünk el, illetôleg a szteroidadag lényegesen csökkenthető [15-17]. A krónikus gyermekkori ITP jelentős hányadában elkerülhető a splenectomia. A mellékhatások ritkák, általában enyhék (fejfájás, infekciók), de esetenként thrombosist, cataractát is leírnak. További hátránya, hogy heti injekciók formájában szükséges adagolni (és drága).

A két, jelenleg rendelkezésre álló thrombocytareceptor-stimuláló készítmény között lényeges terápiás hatékonysági különbség nincs. Ugyanakkor feltétlen megemlítendő, hogy a gyermekek számára kényelmesebb lehet a per os adagolás (eltrombopág), mint a hetente adott sc. injekció (romiplosztim). Újabb adatok arról is beszámolnak, hogy ha az egyik készítményre nincs megfelelő válasz, akkor a másik készítmény még megpróbálandó (switch kezelés) [18]. A hatékonyság a váltás után 50$80 \%$. A két készítmény kombinált adásáról egyelőre kevés az adat. Sok esetben a gyógyszerek adását fel lehet függeszteni és a THR-szám csökkenése esetén újraindítani (így például a költségek is csökkenthetők). Több elsősorban amerikai - ajánlás már másodvonalban javasolja gyermekeknek a TPO-agonistákat [19, 20]. Így a gyermekkori splenectomiák nagy része elkerülhető.

\section{Rituximab}

Anti-CD20 monoklonális ellenanyaggal végzett kezeléssel a B-sejteket lehet kivonni a keringésből, és így az immunválasz megakasztásával potenciálisan pozitív terápiás effektus érhető el. Egyre több irodalmi adat utal az autoimmun folyamatokban, így autoimmun thrombocytopeniákban a rituximab jó terápiás effektusára. Az adag 375 $\mathrm{mg} / \mathrm{m}^{2}$, hetente egyszer, kettő-négy alkalommal. Jelenleg Magyarországon nincs törzskönyvezve a készítmény ezen indikációban. Csak külön egyedi engedéllyel, „offlabel" alkalmazható! A nemzetközi adatok alapján a terápiás válasz 30-65\% [21, 22]. Mellékhatásként súlyos szepszist és elhúzódó hypogammaglobulinaemiát (négyhat hónap) okozhat. Bizonyos rezisztens esetekben megkísérelhető.

\section{Splenectomia}

A lépkivétel csak az életveszélyes vérzéssel járó vagy elhúzódó, súlyos vérzéses epizódokkal, súlyos gyógyszermellékhatással terhelt, a beteg gyermek életminőségét egyértelmúen rontó, életmódját korlátozó krónikus ITP-ben javasolt, lehetőleg öt-hat éves kor felett. A mútét napjainkban preferált formája a laparoszkópos splenectomia. A beavatkozás előtt, lehetőleg nem immunszupprimált állapotban, tokképző kórokozók elleni vakcináció szükséges (Haemophilus, Pneumococcus, Meningococcus ellen). A splenectomia után antibiotikum (penicillinszármazékok) profilaktikus adása javasolt két-három évig. A lépkivétel az esetek mintegy 70\%-ában vezet a thrombocytaszám javulásához vagy normalizálódásához. 


\section{Terápiás alternatívák}

További terápiás alternatívát jelentenek a mikrofenolátmofetil, a nem virilizáló androgénkészítmények, az autológ vagy az allogén haemopoeticus ôssejt átülttetése (extrém ritkán).

A plazmaferézis jelenleg már szintén nem standard terápia, de számos ajánlás még megemlíti $[10,17,21]$, nagyon különböző terápiás hatékonysággal (10-60\%). Kimutatható, kifejezett ellenanyagképzés esetén megkísérelhető.

Fontos kiegészítése az ITP-s betegek ellátásának a beteg életmódjának helyes megválasztása: 100 G/1 alatti THR-szám esetén nem javasoljuk például nagy sérülésveszéllyel járó küzdősportok folytatását. 50 G/l-nél kisebb THR-szám esetén kifejezetten kímélő életmódot javasolunk (például testnevelés alóli felmentéssel, de iskolába járással).

\section{Következtetés}

Megállapítható, hogy a gyermekkori ITP-esetek túlnyomó részében splenectomiára már nincs szükség. A korábban gyakran észlelt, sokszor súlyos, szteroid-mellékhatások részben nagy dózisú IVIG-kezelésekkel, részben az új, innovatív szerekkel (trombopoetinreceptor-stimulálók) nagyrészt csökkenthetők. Ma már Magyarországon is rendelkezésre áll törzskönyvezett készítmény, az eltrombopág, amely lényegesen kevesebb mellékhatással, az esetek döntő részében hatékony.

Anyagi támogatás: A közlemény megírását a Novartis Kft. támogatta.

Szerzői munkamegosztás: A szerző́k egyenlő arányban vettek részt a közlemény megírásában. A cikk végleges változatát mindkét szerző elolvasta és jóváhagyta.

Érdekeltségek: Mindkét szerző tagja a Novartis Hungaria Kft. „Advisory board”-jának. A szerzőknek egyéb érdekeltségük nincs.

\section{Irodalom}

[1] Kiss Cs. Immune thrombocytopenias in childhood. [Immunthrombocytopeniák a gyermekkorban. In: Boda Z. (szerk.): Thrombosis és vérzékenység.] Medicina Könyvkiadó, Budapest, 2006; pp. 208-218. (Hungarian)

[2] Bennett CM, Tarantino M. Chronic immune thrombocytopenia in children: epidemiology and clinical presentation. Hematol Oncol Clin North Am. 2009; 23: 1223-1238.

[3] Kiss Cs, Csóka M, Szegedi I, et al. Up to date treatment of pediatric ITP. [A gyermekkori immun thrombocytopenia (ITP) korszerú ellátása.] Gyermekgyógyászat 2011; 62: 92-97. (Hungarian)

[4] Blanchette V, Bolton-Maggs P. Childhood immune thrombocytopenic purpura: diagnosis and management. Pediatr Clin North Am. 2008; 55: 393-420.
[5] Tarantino MD, Bolton-Maggs PH. Update on the management of immune thrombocytopenic purpura in children. Curr Opin Hematol. 2007; 14: 526-534.

[6] Provan D, Stasi R, Newland AC, et al. International consensus report on the investigation and management of primary immune thrombocytopenia. Blood 2010; 115: 168-186.

[7] Del Vecchio GC, De Santis A, Giordano P, et al. Management of acute childhood idiopathic thrombocytopenic purpura according to AIEOP consensus guidelines. Acta Haematol. 2008; 119: $1-7$.

[8] Kühne T, Buchanan GR, Zimmerman S, et al. A prospective comparative study of 2540 infants and children with newly diagnosed idiopathic thrombocytopenic purpura (ITP) from the Intercontinental Childhood ITP Study Group. J Pediatr. 2003; 143: 605-608.

[9] Watts RG. Idiopathic thrombocytopenic purpura: a 10-year natural history study at the childrens hospital of Alabama. Clin Pediatr (Phila) 2004; 43: 691-702.

[10] Cines DB, Bussel JB. How I treat idiopathic thrombocytopenic purpura (ITP). Blood 2005; 106: 2244-2251.

[11] Burness CB, Keating GM, Garnock-Jones KP. Eltrombopag: A review in pediatric chronic immune thrombopenia. Drugs 2016; 76: 869-878.

[12] Bussel JB, Saleh MN, Vasey SY, et al. Repeated short-term use of eltrombopag in patients with chronic immune thrombocytopenia. Br J Haematol. 2013; 160: 538-546.

[13] Bussel JB, Garcia de Miguel P, Despotovic JM, et al. Eltrombopag for the treatment of children with persistent and chronic immune thrombocytopenia (PETIT): a randomised, multicentre, placebo-controlled study. Lancet Haematol. 2015; 2: e315e325.

[14] Grainger JD, Locatelli F, Chotsampancharoen T, et al. Eltrombopag for children with chronic immune thrombocytopenia (PETIT2): a randomised, multicentre, placebo-controlled trial. Lancet 2015; 386: 1649-1658.

[15] Elalfy MS, Abdelmaksoud AA, Eltonbary KY. Romiplostim in children with chronic refractory ITP: randomized placebo controlled study. Ann Hematol. 2011; 90: 1341-1344.

[16] Cines DB, Wasser J, Rodeghiero F, et al. Safety and efficacy of romiplostim in splenectomized and nonsplenectomized patients with primary immune thrombocytopenia. Haematologica 2017; 102: 1342-1351.

[17] Buchbinder D, Nugent D, Hsieh L. Spotlight on romiplostim in the treatment of children with chronic immune thrombocytopenia: design, development, and potential place in therapy. Drug Des Devel Ther. 2017; 11: 1055-1063.

[18] Khellaf M, Viallard JF, Hamidou M, et al. A retrospective pilot evaluation of switching thrombopoetic receptor-agonists in immune thrombocytopenia. Haematologica 2013; 98: 881-887.

[19] Cooper N. State of the art - how I manage immune thrombocytopenia. Br J Haematol. 2017; 177: 39-54.

[20] Cuker A, Neunert CE. How I treat refractory immune thrombocytopenia. Blood 2016; 128: 1547-1554.

[21] Bennett CM, Rogers ZR, Kinnamon DD, et al. Prospective phase $1 / 2$ study of rituximab in childhood and adolescent chronic immune thrombocytopenic purpura. Blood 2006; 107: 2639-2642.

[22] Citak EC, Citak FE. Treatment results of children with chronic immune thrombocytopenic purpura (ITP) treated with rituximab. J Trop Pediatr. 2011; 57: 71-72.

(Kovács Gábor dr., Budapest, Túzoltó u. 7-9., 1094 e-mail: kovacs.gaborl@med.semmelweis-univ.hu) 